\title{
A SIMPLE AND EFFICIENT MICROPROPAGATION PROTOCOL FOR DEVELOPING PLANTLETS OF EXACUM BICOLOR ROXB. - AN ENDANGERED, ORNAMENTAL, AND ANTIDIABETIC HERB
}

\author{
SHARAD S ACHAR, SAISHA VINJAMURI* \\ Department of Biotechnology, B.M.S. College of Engineering, Bangalore, Karnataka, India. Email: saishav.bt@bmsce.ac.in
} Received: 01 February 2021, Revised and Accepted: 08 March 2021

\begin{abstract}
Objective: Exacum bicolor Roxb. is an endangered medicinal herb due to overexploitation by humans and its inefficient vegetative reproduction. Here, we report an efficient and simple procedure for the regeneration of E. bicolor Roxb. using leaf as an explant.

Methods: The optimal concentrations of the hormones needed for callus induction were determined by full factorial method using DOE (Design expert ver. 8.0). The hormones selected based on literature were kinetin, indole acetic acid, and 6-Benzylaminopurine (BAP). Multiple shoot regeneration was carried out in liquid and solid media with the optimal concentrations of the hormones obtained by DOE. Rooting was initiated using Murashige and Skoog media containing naphthalene acetic acid $0.5 \mathrm{mg} / \mathrm{l}$, indole butyric acid (IBA) $1.0 \mathrm{mg} / \mathrm{l}$, and gibberellic acid $30.5 \mathrm{mg} / \mathrm{l}$ along with $0.2 \%$ of
\end{abstract} activated charcoal.

Results: Analysis of full factorial design run showed that BAP in combination with kinetin was effective for the growth of callus and multiple shoot regeneration was higher in liquid media (81.25\%). The rate of rooting was observed to be $88.23 \%$ and the average number of roots was 0.26 . Plantlets with budding apical region and well-established leaves and roots were observed in 30 days.

Conclusion: The protocol reported here can be used for effective production of $E$. bicolor plants in a shorter duration compared to the conventional approach.

Keywords: Exacum, DOE, Regeneration of plantlets.

(C) 2021 The Authors. Published by Innovare Academic Sciences Pvt Ltd. This is an open access article under the CC BY license (http://creativecommons.org/ licenses/by/4.0/) DOI: http://dx.doi.org/10.22159/ajpcr.2021v14i5.40966. Journal homepage: https://innovareacademics.in/journals/index.php/ajpcr

\section{INTRODUCTION}

Plants of genera Exacum (Gentianaceae) are well known for their ornamental [1,2] and medicinal properties [3-5]. These plants are mostly found in the temperate and subtropical regions and include about 1738 species. So far, around 153 species from 17 genera have been identified in India [6]. The plant grows to a height of 25-120 cm and its vegetative phase is from June to August with a flowering period from September to November $[7,8]$.

In recent times, there has been a rapid decline of its population due to loss of its habitat. The approach currently being used to increase their population is by seed germination. However, it is difficult to reproduce these plants due to the high rate of seed dormancy $[7,9,10]$.

Hence, plant tissue culture is a viable option for increasing its population. Many in vitro culture protocols have been developed from nodal regions of the plant $[1-3,11,12]$. However, it has been observed that micropropagation by these methods is elaborate, not highly successful and time consuming.

Here, we report a simple and efficient protocol for developing plantlets from leaf explants. Full factorial design was used to predict the optimal concentrations of the hormones for obtaining a well-developed callus within 30 days. The leaves from a well-grown healthy flowering plant were used as explant for developing plantlets. Further, these plantlets were grown on shooting and rooting media to obtain a complete plant.

\section{METHODS}

The Murashige and Skoog (MS) media and the hormones naphthalene acetic acid (NAA), IBA, BAP, and kinetin were procured from HiMedia, India, and gibberellic acid 3 (GA3) was procured from LOBA Chemie, India.
Preparation of explants and shoot bud initiation

The plant Exacum bicolor was obtained from the hilly regions of Sakaleshpura (Bisele ghat) and authenticated by NADRI-Ministry of AYUSH in Bengaluru-India (Fig. 1). It was collected in early September when the flowers had just bloomed and new buds were developing in the apical region of the plant. The young and tender leaves of the plant were used as explant in our studies.

Surface sterilization was performed as per the standard protocol given by Bhojwani and Razdan [13]. The leaf explants of $0.5 \times 0.5 \mathrm{~cm}$ were inoculated into $25 \mathrm{ml}$ of MS media supplemented with plant growth regulators.

Factorial design of $2^{\wedge} 3$ (Design expert Ver. 8.0) was used to obtain the optimal concentrations of the plant hormones for maximal callus production. Three hormones, namely, BAP, indole acetic acid (IAA), and kinetin were selected at two levels (high and low values) based on available literature $[3,7,8,14]$.

The experiments were conducted as per the DOE generated (Table 1) for the three hormones at two levels, namely, BAP (0.1-2.5 mg/l), IAA $(0.0-0.5 \mathrm{mg} / \mathrm{l})$, and kinetin $(0.0-3.0 \mathrm{mg} / \mathrm{l})$. The response was considered with respect to weight of callus and growth in days. ANOVA was used to determine the significance of the factors. The leaf explants were inoculated into the tissue culture flasks as per DOE and incubated at $24 \pm 2^{\circ} \mathrm{C}$ under a $16 / 8 \mathrm{~h}$ (light/dark cycle) photoperiod provided with cool white fluorescent light (1500-3000 Lux) for 30 days.

\section{Shoot proliferation}

A well-developed greenish rounded callus (1 g) obtained from the explants was used for shoot proliferation. The callus obtained was dissected aseptically $(1.0-1.5 \mathrm{~cm})$ and reinoculated into MS media containing BAP $10 \mu \mathrm{M}$ and kinetin $2 \mu \mathrm{M}$ to develop florets as per the 
Table 1: Factorial design of $2^{\wedge} 3$ DOE generated using Design expert Ver. 8.0

\begin{tabular}{lllllll}
\hline Std. & Run & $\begin{array}{l}\text { Factor } \mathbf{1} \\
\text { A: BAP } \mathbf{~ m g} / \mathbf{l}\end{array}$ & $\begin{array}{l}\text { Factor } \mathbf{2} \\
\text { B: } \mathbf{1 A A} \mathbf{~ m g} / \mathbf{l}\end{array}$ & $\begin{array}{l}\text { Factor } \mathbf{3} \\
\text { C: Kinetin } \mathbf{~ m g} / \mathbf{l}\end{array}$ & $\begin{array}{l}\text { Response } \mathbf{1} \\
\text { growth in days }\end{array}$ & $\begin{array}{l}\text { Response 2 } \\
\text { weight of callus }\end{array}$ \\
\hline 1 & 1 & 0.10 & 0.00 & 0.00 & \\
6 & 2 & 2.50 & 0.00 & 3.00 & \\
4 & 3 & 2.50 & 0.50 & 0.00 & \\
5 & 4 & 0.10 & 0.00 & 3.00 & \\
8 & 5 & 2.50 & 0.50 & 3.00 & \\
3 & 6 & 0.10 & 0.50 & 0.00 & \\
2 & 7 & 2.50 & 0.00 & 0.00 & \\
7 & 8 & 0.10 & 0.50 & 3.00 & \\
\hline
\end{tabular}

Table 2: ANOVA for response with respect to growth

Response 1 growth ANOVA for selected factorial model analysis of variance table (partial sum of squares - Type III)

\begin{tabular}{|c|c|c|c|c|c|}
\hline \multirow[t]{2}{*}{ Source } & \multirow{2}{*}{$\begin{array}{l}\text { Sum of } \\
\text { squares }\end{array}$} & \multirow[t]{2}{*}{ df } & \multirow{2}{*}{$\begin{array}{l}\text { Mean } \\
\text { square }\end{array}$} & $\mathbf{F}$ & \multirow{2}{*}{$\begin{array}{l}\text { p-value } \\
\text { Prob > F }\end{array}$} \\
\hline & & & & Value & \\
\hline Model & 165.75 & 6 & 27.63 & 221.00 & $\begin{array}{l}0.0514 \text { not } \\
\text { significant }\end{array}$ \\
\hline A-BAP & 0.13 & 1 & 0.13 & 1.00 & 0.5000 \\
\hline B-IAA & 28.13 & 1 & 28.13 & 225.00 & 0.0424 \\
\hline C-Kinetin & 21.13 & 1 & 21.13 & 169.00 & 0.0489 \\
\hline $\mathrm{AB}$ & 55.13 & 1 & 55.13 & 441.00 & 0.0303 \\
\hline $\mathrm{AC}$ & 55.12 & 1 & 55.12 & 441.00 & 0.0303 \\
\hline BC & 6.13 & 1 & 6.13 & 49.00 & 0.0903 \\
\hline Residual & 0.12 & 1 & 0.12 & & \\
\hline Cor Total & 165.88 & 7 & & & \\
\hline
\end{tabular}

The model F-value of 221.00 implies that there is a $5.14 \%$ chance that a "Model F-Value" This large could occur due to noise. Values of "Prob $>F$ " $<0.0500$ indicate model terms are significant. In this case, B, C, AB, and AC are significant model terms. Values greater than 0.1000 indicate the model terms are not significant. If there are many insignificant model terms (not counting those required to support hierarchy), model reduction may improve your model

\begin{tabular}{llll}
\hline Std. Dev. & 0.35 & R-Squared & 0.9992 \\
Mean & 19.38 & Adj R-Squared & 0.9947 \\
C.V. \% & 1.82 & Pred R-Squared & 0.9518 \\
PRESS & 8.00 & Adeq Precision & 33.261 \\
\hline
\end{tabular}

The "Pred R-Squared" of 0.9518 is in reasonable agreement with the "Adj R-Squared" of 0.9947. "Adeq Precision" measures the signal-tonoise ratio. A ratio greater than 4 is desirable. Your ratio of 33.261 indicates an adequate signal. This model can be used to navigate the design space

\begin{tabular}{|c|c|c|c|c|c|c|}
\hline \multicolumn{3}{|c|}{ Coefficient standard } & \multicolumn{2}{|c|}{$95 \%$ CI } & \multicolumn{2}{|c|}{$95 \% \mathrm{CI}$} \\
\hline Factor & Estimate & Df & Error & Low & High & VIF \\
\hline Intercept & 19.38 & 1 & 0.12 & 17.79 & 20.96 & \\
\hline A-BAP & 0.12 & 1 & 0.12 & -1.46 & 1.71 & 1.00 \\
\hline B-IAA & 1.87 & 1 & 0.12 & 0.29 & 3.46 & 1.00 \\
\hline C-Kinetin & -1.63 & 1 & 0.12 & -3.21 & -0.037 & 1.00 \\
\hline $\mathrm{AB}$ & 2.63 & 1 & 1 & 1.04 & 4.21 & 1.00 \\
\hline $\mathrm{AC}$ & 2.63 & 1 & 1 & 1.04 & 4.21 & 1.00 \\
\hline $\mathrm{BC}$ & 0.88 & 1 & 1 & -0.71 & 2.46 & 1.00 \\
\hline
\end{tabular}

Final equation in terms of coded factors: Growth $=+19.38+0.12 * \mathrm{~A}+1.87 * \mathrm{~B}-$ $1.63 * \mathrm{C}+2.63 * \mathrm{~A}^{*} \mathrm{~B}+2.63^{*} \mathrm{~A}^{*} \mathrm{C}+0.88 * \mathrm{~B} * \mathrm{C}$

Final equation in terms of actual factors: Growth $=+25.55208-4.27083 * \mathrm{BAP}-$

7.37500*IAA-3.56250*Kinetin+8.75000*BAP*IAA+1.45833*BAP*Kinetin+2.33 $333 *$ IAA* Kinetin

protocol given by Appaji et al. [12]. They were incubated at $24 \pm 2^{\circ} \mathrm{C}$ under a 16/8 h (light/dark cycle) photoperiod provided with cool white fluorescent light (1500-3000 Lux).

After incubation, the percentage of shoot induction, time taken for bud initiation (marked by a separation layer on the edges of the petiole), and the growth rate of the buds were recorded.
Table 3: ANOVA for response with respect to weight of callus

Response 2 weight of callus ANOVA for selected factorial model analysis of variance table (partial sum of squares - Type III)

\begin{tabular}{|c|c|c|c|c|c|c|}
\hline \multirow[t]{2}{*}{ Source } & \multirow{2}{*}{$\begin{array}{l}\text { Sum of } \\
\text { squares }\end{array}$} & \multirow[t]{2}{*}{ df } & \multirow{2}{*}{$\begin{array}{l}\text { Mean } \\
\text { square }\end{array}$} & \multirow[t]{2}{*}{$\mathbf{F}$} & \multicolumn{2}{|c|}{ p-value } \\
\hline & & & & & Value & Prob $>$ F \\
\hline Model & 0.10 & 6 & 0.017 & 10.42 & 4.76 & 0.2736 \\
\hline A-BAP & 7.744E-003 & 1 & 7.744 & E-003 & 0.1139 & \\
\hline B-IAA & 0.050 & 1 & 0.050 & 30.57 & 5.85 & 0.2496 \\
\hline C-Kinetin & $9.515 \mathrm{E}-003$ & 1 & 9.515 & E-003 & 3.33 & 0.3193 \\
\hline $\mathrm{AB}$ & $5.413 \mathrm{E}-003$ & 1 & 5.413 & E-003 & 0.024 & 0.9031 \\
\hline $\mathrm{AC}$ & $3.828 \mathrm{E}-005$ & 1 & 3.828 & E-005 & 0.1475 & \\
\hline $\mathrm{BC}$ & 0.029 & 1 & 0.029 & 17.97 & & \\
\hline Residual & $1.627 \mathrm{E}-003$ & 1 & 1.627 & E-003 & & \\
\hline Cor total & 0.10 & 7 & & & & \\
\hline
\end{tabular}

The "Model F-value" of 10.42 implies the model is not significant relative to the noise. There is $23.28 \%$ chance that a "Model F-value" this large could occur due to noise. Values of "Prob > F" less than 0.0500 indicate model terms are significant. In this case, there are no significant model terms. Values greater than 0.1000 indicate the model terms are not significant. If there are many insignificant model terms (not counting those required to support hierarchy), model reduction may improve your model

\begin{tabular}{llll}
\hline Std. Dev. & 0.040 & R-Squared & 0.9843 \\
Mean & 0.61 & Adj R-Squared & 0.8898 \\
C.V. \% & 6.62 & Pred & 0.0079 \\
& & R-Squared & \\
PRESS & 0.10 & $\begin{array}{l}\text { Adeq } \\
\text { Precision }\end{array}$ & 8.917 \\
& & Prion & \\
\hline
\end{tabular}

A negative "Pred R-Squared" implies that the overall mean is a better predictor of your response than the current model. "Adeq Precision" measures the signal-to-noise ratio. A ratio greater than 4 is desirable. Your ratio of 8.917 indicates an adequate signal. This model can be used to navigate the design space

\begin{tabular}{|c|c|c|c|c|c|c|}
\hline \multirow{2}{*}{$\frac{\text { Coefficient }}{\text { Factor }}$} & \multicolumn{2}{|l|}{ Standard } & \multicolumn{2}{|c|}{$95 \%$ CI } & \multicolumn{2}{|c|}{$95 \%$ CI } \\
\hline & Estimate & df & Error & Low & High & VIF \\
\hline Intercept & 0.61 & 1 & 0.014 & 0.43 & 0.79 & \\
\hline A-BAP & 0.031 & 1 & 0.014 & -0.15 & 0.21 & 1.00 \\
\hline B-IAA & -0.079 & 1 & 0.014 & -0.26 & 0.10 & 1.00 \\
\hline C-Kinetin & 0.034 & 1 & 0.014 & -0.15 & 0.22 & 1.00 \\
\hline $\mathrm{AB}$ & -0.026 & 1 & 0.014 & -0.21 & 0.16 & 1.00 \\
\hline $\mathrm{AC}$ & $2.188 \mathrm{E}-003$ & 1 & 0.014 & -0.18 & 0.18 & 1.00 \\
\hline $\mathrm{BC}$ & 0.060 & 1 & 0.014 & -0.12 & 0.24 & 1.00 \\
\hline
\end{tabular}

Final equation in terms of coded factors: Weight of callus

$=+0.61+0.031 * \mathrm{~A}-0.079 * \mathrm{~B}+0.034^{*} \mathrm{C}-0.026^{*} \mathrm{~A} * \mathrm{~B}+2.188 \mathrm{E}-003 * \mathrm{~A} * \mathrm{C}+0.060 * \mathrm{~B} * \mathrm{C}$ Final equation in terms of actual factors: Weight of callus $=+0.65468+0.045781 *$ BAP- $0.44458 *$ IAA- $0.018897 *$ Kinetin -

0.086708*BAP*IAA+1.21528E-003*BAP*Kinetin+0.16123*IAA*Kinetin

The florets developed were reintroduced into both solid and liquid media of the same composition incubated. The multiplication rate and number of new shoots per explant which were greater than $0.5 \mathrm{~cm}$ were recorded. 


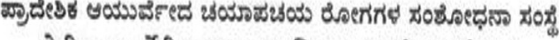
क्षेत्रीय आयुद्वेदीय चयापचय विकार अनुसंधान संस्थान

(केंद्रीय आयुर्वेदीय विज्ञान अनुसंधान परिकदू, आयुष मंत्रालय, भारत सरकाए

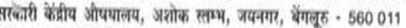

REGIONAL AYURVEDA RESEARCH INSTITUTE FOR METABOLIC DISORDERS

(Contral Council for Resoarch in Ayurvedic Seiences, Ministry of AYUSH, Govt. of India) Telefax : 080-26562030, Ph. : 26572207, E-mail : nadri-bengalurugagov. in, nadri.bengalurul@gmail.con

प्रमाणीकरण/औ.पौ.स.इ./आर.ए.आर.ऐ. एम.९ि,/बेंगलुस/2016-17/ दिनांक /Date: 30.09.2016 Authentication/SMPU/RARIMD/BNG/2016.17/

\section{प्रमाणपत्र/CERTIFICATE}

शरद एस, संसोधन खत्र, जैव प्रौद्योगिकी विभाग, बी एम एस इंजीनियरिंग कॉलेज, बैगलु के द्वारा प्रस्तुत किया गया पौधों का नमूने को नीचे लिखा हुए नाम से पहचान के प्रमाणीकृत किया जाता है।

This is to certify that the plant samples submitted by Starad S., Ph.D Student, Department of Biotechnology, BMS College of Enginecring, Bengaluru have been identified and authenticated as Exacum bicolor Roxb. [Syn: Exacum tetraganum Roxb.] belonging to Family Gentianaceae (RRCBI- 4009)

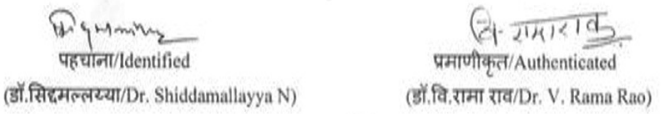

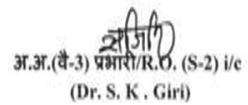

Fig. 1: Authentication of the plant by NADRI-Ministry of AYUSH in Bengaluru, India

\section{Rooting}

Individual shoots ( $>1.2 \mathrm{~cm}$ height) obtained from liquid culture were cut off and transferred into rooting media, namely, MS media containing NAA $0.5 \mathrm{mg} / \mathrm{l}$, IBA $1.0 \mathrm{mg} / \mathrm{l}$, and GA3 $0.5 \mathrm{mg} / \mathrm{l}$ and $0.2 \%$ of activated charcoal. The plantlets were incubated at $24 \pm 2^{\circ} \mathrm{C}$ under a $16 / 8 \mathrm{~h}$ (light/ dark cycle) photoperiod provided with cool white fluorescent light (1500-3000 Lux).

The percentage of root induction, root numbers, and the growth rate of roots were observed and recorded. Observations were recorded at regular intervals of $48 \mathrm{~h}$.

The induction rate, multiplication, and rooting rate were calculated as given below.

Induction rate $(\%)=$ The number of induced explants/the number of total initial explants $\times 100 \%$.

Multiplication rate $(\%)=$ The total number of buds $(\geqq 0.3 \mathrm{~cm}) /$ the number of initial buds on the sub cultured explants $\times 100 \%$.

Rooting rate $(\%)=$ The number of the rooted plantlets/the number of total shoots $\times 100 \%$.

Average number of roots $=$ The total number of roots/the number of rooted seedlings.

\section{RESULTS AND DISCUSSION}

\section{Preparation of explants and shoot bud initiation}

The young tender leaves of the plant were used as explants. Factorial design of $2^{\wedge} 3$ (Design expert Ver. 8.0) was used to obtain the optimal concentrations of the plant hormones for maximal callus production. The experiments were conducted as per the DOE generated for the three hormones at two levels, namely, BAP (0.1-2.5 mg/l), IAA (0.0-0.5 mg/l), and kinetin $(0.0-3.0 \mathrm{mg} / \mathrm{l})$ and the response was considered with respect to weight of callus and growth in days. The ANOVA with respect to growth and weight of

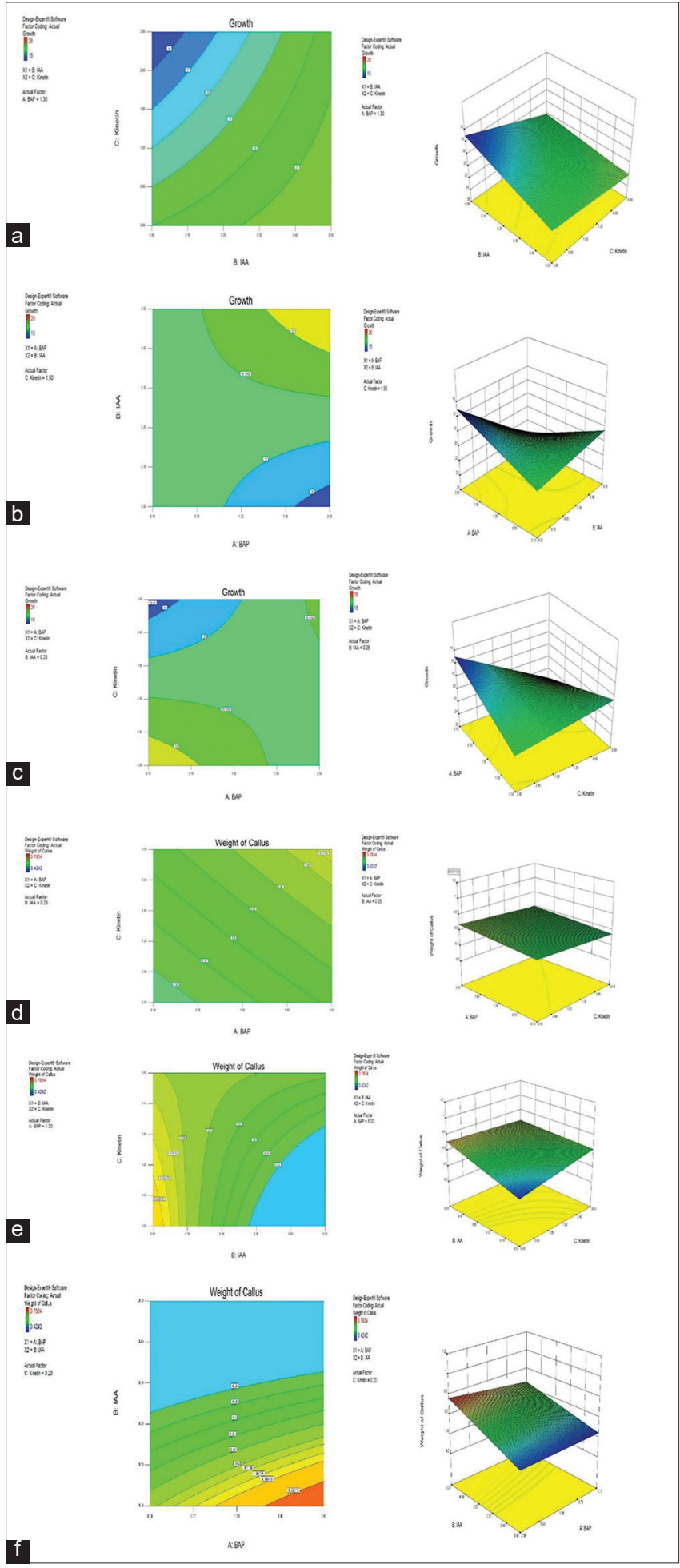

Fig. 2: (a) Contour plots of growth response with KINETIN and

IAA. (b) Contour plots of growth response with BAP and IAA.

(c) Contour plots of growth response with BAP and kinetin.

(d) Contour plots of weight of callus with BAP and kinetin. (e) Contour plots of weight of callus with IAA and kinetin. (f) Contour plots of weight of callus with IAA and BAP

callus is shown in Tables 2 and 3, respectively. The contour plots of the responses are shown in Fig. 2a-f. Healthy greenish callus was formed from the explants within 40 days. It was observed that BAP in combination with kinetin was effective for the rapid growth of callus (Fig. 3). Hence, these concentrations were considered for all further studies. 


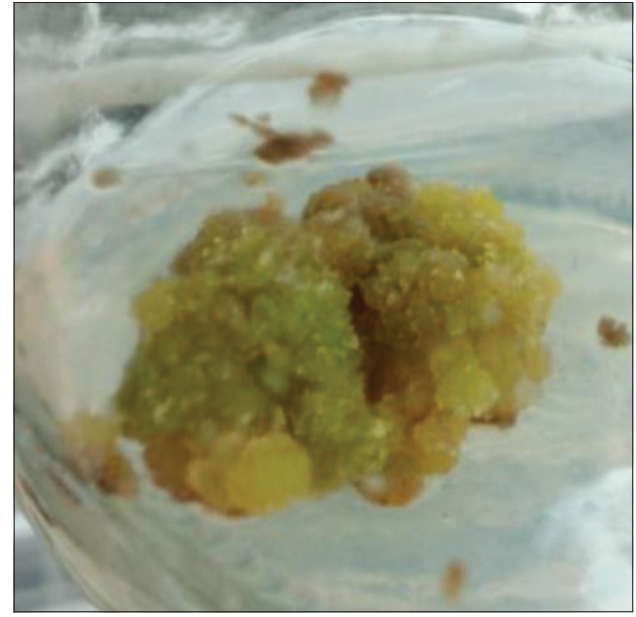

Fig. 3: Callus developed from leaf explants
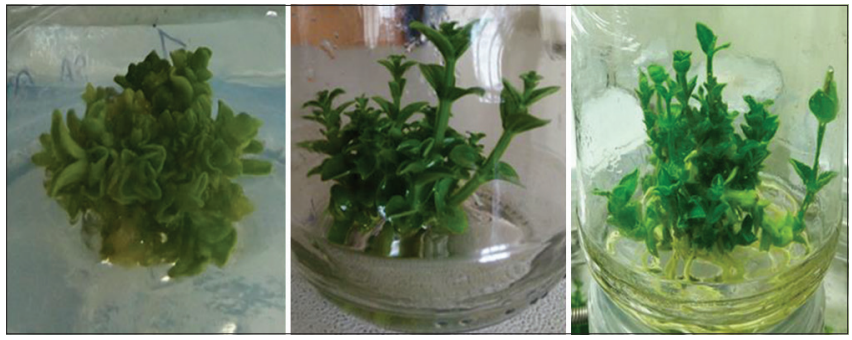

Fig. 4: Florets developed in solid and liquid media from the callus in 20 days
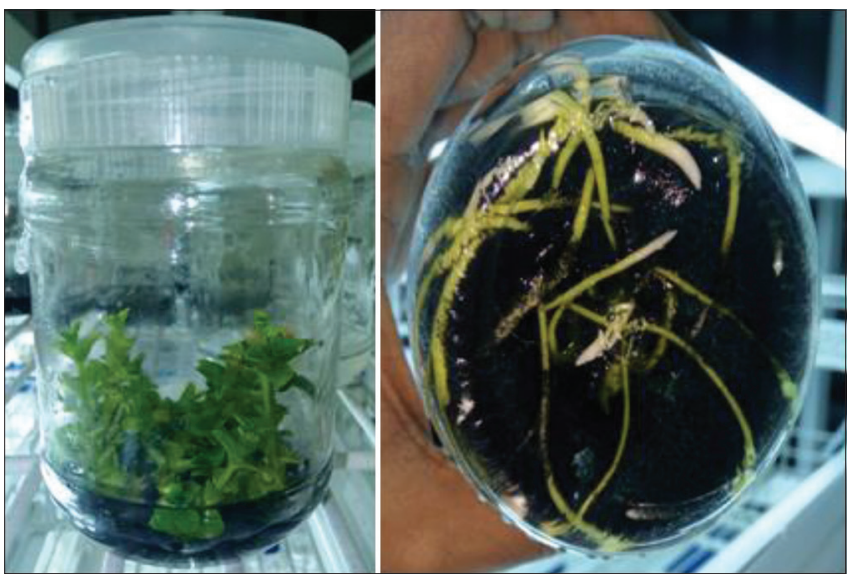

Fig. 5: Plantlets bearing roots grown in the rooting medium with activated charcoal

\section{Shoot proliferation}

A well-developed greenish rounded callus (1 g) obtained from the explants was used in shoot proliferation. The induction rate of the explants was $500 \%$ and shoot proliferation rate was $75 \%$. The time taken for bud proliferation was 60 days.

The florets developed were reintroduced into both solid and liquid media of the same composition and incubated. After 15 days, better plantlet formations were observed in liquid media compared to solid media. The florets formed were well developed with distinct nodal regions and leaves at each node. The multiplication rate was $81.25 \%$ in liquid media.

\section{Rooting}

Individual shoots ( $\geqq 1.2 \mathrm{~cm}$ height) obtained from liquid culture were cut off and transferred into rooting media (Fig. 4). The initial growth of roots from the base of the plantlets was observed within 3 weeks. Twenty-four plantlets with well-established roots and green leaves at every node with a budding apical region were observed within 30 days (Fig. 5). The rate of rooting was $88.23 \%$ and the average number of roots was 0.26

\section{CONCLUSION}

Many studies have reported the conventional method for micropropagation of plants belonging to this genus [2,3,14-17]. Obtaining the plantlets by the conventional method of propagation involves the usage of nodal regions as explants $[11,12]$ and the duration required to obtain plantlets varies from 90 days to 112 days. Here, we report a modified protocol which can produce plantlets with wellestablished roots in 90-110 days.

\section{ACKNOWLEDGMENTS}

The authors would like to thank TEQIP-2 and TEQIP-3 for providing financial assistance during this research work.

\section{AUTHORS' CONTRIBUTIONS}

S.S.A. has performed the experiments. S.V. has supervised the study. Both S.S.A. and S.V. have contributed to the final version of the manuscript.

\section{CONFLICTS OF INTEREST}

The authors declare that there are no conflicts of interest.

\section{AUTHORS' FUNDING}

This research work was financially funded by Technical Education Quality Improvement Programme - II and III (TEQIP-II and III) in BMS College of Engineering - Bengaluru.

\section{REFERENCES}

1. Kannan P, Premkumar A, Ignacimuthu S. Thidiazuron induced shoot regeneration in the endangered species, Exacum travancoricum Beedi. Indian J Biotechnol 2007;6:564-6.

2. Nisakorn S, Kitti B, Sompoch N, Parutuch L, David WM. Microshoot culture of Persian violet: Plant regeneration and in vitro flowering. Ann Agric Sci 2017;62:105-11.

3. Baluprakash T, Arumugasamy K, Paulsamy S, Udhayasankar MR, Danya U. In vitro regeneration of Exacum wightianum Arn. (Gentianaceae) an endemic medicinal plant from The Nilgiris, Western Ghats. J Appl Pharm Sci 2011;01:167-71.

4. IMPATT. Chennai, India: The Indian Institute of Mathematical Sciences; c2021. Available from: https://www.cb.imsc.res.in/imppat/ Phytochemical/Exacum\%20bicolor. [Last accessed $2021 \mathrm{Feb} 24$ ].

5. Shiddamallayya N, Arza Y, Gopakumar K. Medico-botanical survey of Kumaraparvatha Kukke Subramanya, Mangalore Karnataka. Indian J Tradit Knowl 2010;9:96-9.

6. Shahina PM, Nampy S. Medicinal plant systematics of Gentianaceae in South India. South Indian J Biol Sci 2016;2:162-8.

7. Sreelatha U, Baburaj TS, Kutty CN, Nazeem PA, Bhaskar J. Cultivation prospects of Exacum bicolor Roxb. An endangered, ornamental and anti-diabetic herb. Indian J Nat Prod Resour 2007;6:402-4.

8. Ashwini HS, Avinash KS, Shravanakumar S, Krishnamurthy YL. Ecology and phenology of plant communities of Gentianaceae in montane grasslands of Karnataka, Southern India. Trop Plant Res 2014; $1: 43-8$

9. Tennakoon S, Peiris SE, Eeswara JP. In vitro regeneration of Exacum trinervium. Acta Hortic 2015;1104:237-44.

10. Behera MC, Raina R. Gentiana kurroo royle a critically endangered bitter herb. Int J Med Arom Plants 2012;2:22-9.

11. Jeeshna MV, Paulsamy S. Evaluation of certain flavonoids of medicinal importance in the wild and micropropagated plants of the endangered medicinal species, Exacum bicolor Roxb. J Appl Pharm Sci 2011;1:99-102.

12. Appaji MA, Hanumanthaiah R, Shirugumbi HM, Majumdar M. An efficient multiple shoot induction and genetic fidelity assessment of Exacum bicolor Roxb., an endemic and endangered medicinal plant. In Vitro Cell Dev Biol Plant 2015;51:1-10.

13. Bhojwani SS, Razdan MK. Plant Tissue Culture: Theory and Practice. 
$1^{\text {st }}$ ed. Amsterdam, The Netherlands: Elsevier; 1986.

14. Janarthanam B, Sumathi E. In vitro plant regeneration from shoot tip explants of Exacum travancoricum Beedi. Plant Tissue Cult Biotech 2010;20:113-8.

15. Riseman A, Chennareddy S. Genotypic variation in the micropropagation of Sri Lankan Exacum hybrids. J Am Soc Hortic Sci 2004;129:698-703.

16. Gruev B, Nikolova M, Donev A. In: Kapchina-Toteva VM, Elena TI,
Ivan PC, editors. Effect of cytokinins on in vitro cultured Exacum affine Balf. Plovdiv, Bulgaria: Proceedings of the Balkan Scientific Conference of Biology May 2005; 2005.

17. Elangomathavan R, Prakash S, Kathiravan K, Seshadri S, Ignacimuthu S. Plant regeneration through micropropagation from nodal explants of critically endangered and endemic plant Exacum travancoricum Beedi. J Plant Biotechnol 2006;8:51-5. 